International Journal of Physical Sciences and Engineering
Available online at http://sciencescholar.us/journal/index.php/ijpse
Vol. 2 No. 3, December 2018, pages: 43 50
e-ISSN : 2550-6943, p-ISSN : 2550-6951
https://doi.org/10.29332/ijpse.v2n3.199

\title{
Packaging Sixto Duran Ballen and the Dam La Esperanza
}

\author{
Gloria Santana Parrales a, Beatriz Irene Caballero Giler b, Maria Shirlendy Guerrero Alcivar c
}

Article history: Received 15 April 2018, Accepted: 11 September 2018, Published: 19 September 2018

Correspondence Author ${ }^{\text {a }}$

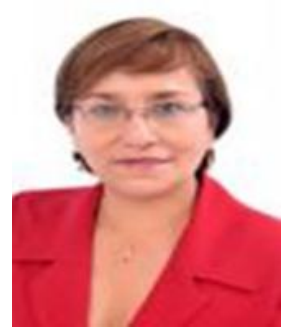

\section{Keywords}

Dams;

Environmental impacts;

Indicators;

Preventive measures;

Reservoirs;

\begin{abstract}
The dam is a reservoir that stores about $450,000,000$ cubic meters of water, has multiple purposes allowing flood control, produces irrigation water, for human consumption and shrimp farming in the area center of the province of Manabí. The first studies for the construction of the dam were carried out in the years 1970 to 1975 as a result of the hydrological/economic feasibility plan of the Province of Manabí, and of the integral hydro-agricultural area of the Carrizal Chone Basin. After several preliminary studies with different international firms and with changes of designs in 1992, the Dragados and Constructions SA Company was in charge of the construction of what is now the Manabí water project. It is located in the parish of Quiroga approximately 12 kilometers from the cantonal canton of Bolívar Canton, Calceta, with an extension of 2,500 hectares, with a construction area of 120 hectares and will allow irrigation of 17,000 hectares of the central area of Manabí. The objective of the work is to make an analysis of the construction of the La Esperanza dam. For this, the logical historical method was used, as well as the bibliography search to know the historical construction of the dam, as well as the observation method.
\end{abstract}

e-ISSN: 2550-6943, p-ISSN: 2550-6951 ๔Copyright 2018. The Author. SS Journals Published by Universidad Técnica de Manabí. This is an open-access article under the CC BY-SA 4.0 license (https://creativecommons.org/licenses/by-sa/4.0/) All rights reserved.

\section{Contents}

Abstract 43

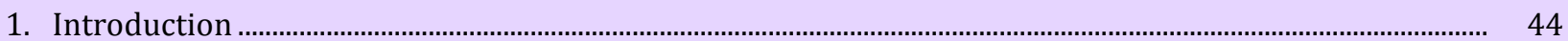

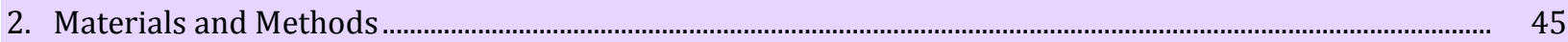

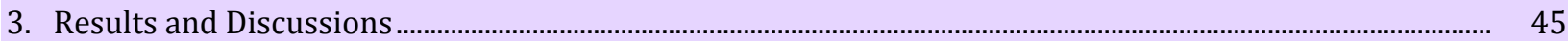

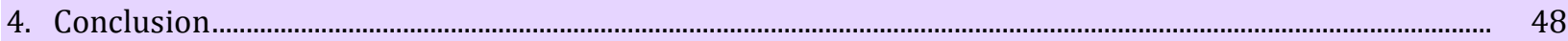

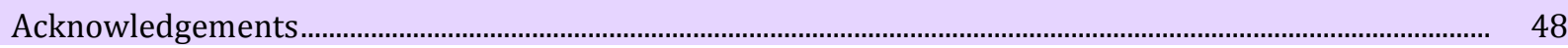

a MsC. Universidad Técnica de Manabí, Portoviejo, Ecuador

b MsC. Universidad Técnica de Manabí, Portoviejo, Ecuador

c MsC. Universidad Técnica de Manabí, Portoviejo, Ecuador 


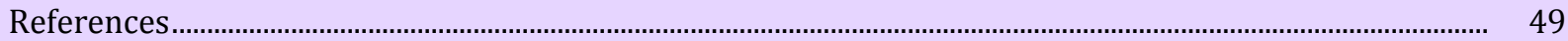

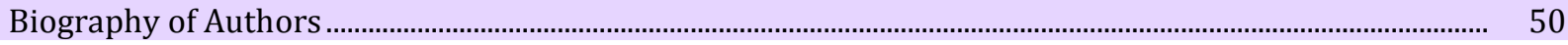

\section{Introduction}

The field of engineering is wide has dissimilar utilities at the time of preparing the design and construction of works of any kind, including mega structures or mega-dams, are characterized primarily by the impacts they cause in the environment where the work is performed (Ribera Arismendi, 2018), although they stand out for having multiple uses, one of the problems that most affects are the impacts they cause in the construction process to the environment (Martínez Yrízar, 2012), this is the case of dams or dams that have large capacity reservoirs (works related to regulating and distributing water resources).

Normally reservoirs are large stores of water volumes whose use can be used for tasks such as water supply for human consumption, animal and irrigation in agriculture, erosion control, rolling, power generation, although there are authors who state that these are not clean energies (Arismendi, 2018; Lay, 2018), according to this author the erroneous assertions about the character of clean energy that is conferred to mega hydroelectric dams are based solely on the reports and biased studies of ill-intentioned technocrats who try to demonstrate the supposed low greenhouse gas (GHG) emissions of hydroelectric plants with partial measurements or in the precarious environmental impact studies of mega dams that also minimize the levels of emissions and distort information.

In some cases, these mega-dams are used for tourism and even recreation, but there are sites such as Chile that value the construction and operation of large reservoirs and dams with their corresponding electric transmission lines would attack the main competitive advantage of the tourism sector (Gabriel Inostroza, 2014). Until recently, large dams were considered a milestone in the development plans of a nation and frequently, they were seen as a symbol of modernity and economic progress (López-Pujol, 2008).

Although the benefits of building large capacity reservoirs are considerable and must be recognized, their negative effects can be immense and, in the case of large dams, often outweigh the positive ones. The list of problems associated with this type of engineering work is long and highlights the environmental and social consequences. The primary effect of the dams is the modification of the course of the river, which can result in a series of changes in the natural environment, such as its transformation, fragmentation or total disappearance (Rosenberg, 2000).

At the same time, in a reservoir dam, there must be important works that capture, conduct or control the passage of the water and its destination, without forgetting the works that are in charge of the excesses of water that exceed the level of design. Observing the importance that the construction of this type of civil works contributes and delimiting the work to the information possibilities referring to the subject of Dams and Reservoirs, it was proposed that the investigation be directed to the study of the "Sixto Durán Ballén" reservoir and its prey "La Esperanza", located in the Calceta parish of Bolívar canton, province of ManabíEcuador. To this end, a meticulous investigation has been carried out in which knowledgeable institutions were consulted on the subject, such as the National Water Secretariat (SENAGUA), bibliographical searches, historical diagrams and important data of the reservoir dam, and finally the technical visit to the place of study with which it was possible to appreciate closely all the consulted and to show the importance of the work proposed.

Description of the materials used in the construction of the dam, mainly made of cement, sand, stone, clayey earth, clay shoulders, ball stone, concrete, grass, plastic pipes, the construction system is concrete through pumping, based on soil accumulation where moisture is tested and compacted. The drainage gallery are tunnels that run along both sides of the dam, the excavation is mechanical and is based on explosives, structural fences and concrete coverings have been placed in its surroundings; with a waterproofing screen that is an element that serves to prevent water seepage under the body of the dam, this screen is placed on the entire axis of the dam. The objective of the investigation is to know the construction form of the dam and its characteristics that allows the students to have a clear idea of its construction, uses, and impacts to the environment. 


\section{Materials and Methods}

To carry out this study, Sixto Durán Ballén Reservoir and its La Esperanza Dam were visited. It is located in the Bolívar canton, north of the province of Manabí, to have a better reference of the place this canton limits with its limits by West: Tosagua Canton, $13 \mathrm{~km}$ southeast of the Calceta parish of Bolívar canton, located in the middle channel of the Tosagua or Carrizal river and below the confluence of the Barro and Cañas rivers. The reservoir dam was characterized as a structure already established, determining its period of usefulness, volumes and characteristic heights of the reservoir, as well as its storage capacity, the year of construction, its risks and benefits for the community, were also investigated. technical bibliography to know the data necessary for the development of the research.

\section{Results and Discussions}

The Sixto Durán Ballén Reservoir is a reservoir classified as a multiple use reservoir, it is characterized within this typology by fulfilling functions such as Supply of water destined for human consumption to the cantons of the central area of the province of Manabí, the aqueducts; Water supply for irrigation, operational reservoirs; Flood control, lamination. Within the category of the reservoir it enters as a medium reservoir. These assignments have been considered by the United Nations (UN) for Food and Agriculture (FAO).

In the years 1970 to 1975, the first studies began under the name of the Manabí Hydrological-Economic Feasibility Plan, since in the Carrizal Chone basin studies were already accentuated, all these works were developed by international firms.

\section{Characteristics and extensions of the reservoir}

The Sixto Durán Ballén reservoir is considered perhaps the appropriate point to achieve the integrated agricultural development of the area that forms the confluence of the Carrizal and Chone rivers, has a storage capacity of 450,000,000 (m3) and in an area of 2400 ha. This work is considered one of the waterworks that supplies the province, as it derives water from a wide area in which the cantons of Bolívar, Junín, Tosagua, and Chone are, and at the same time, it supplies water to 2,800 hectares of crops.

The demands for raw water are estimated at $260,000,000 \mathrm{~m} 3$ annually, which are distributed to meet the demand for potable water by some $20,000,000 \mathrm{~m} 3$ and for irrigation $240,000,000 \mathrm{~m} 3$. This dam also receives the outstanding flows of the Daule-Peripa reservoir, the first of a transfer for use in the Poza Honda reservoir with a second transfer. The demand for water for irrigation satisfies around $25.00 \mathrm{Ha}$. The Poza Honda dam has an embankment height of 47 meters and Coronation length of 700 meters.

The Esperanza Dam consists of shoulders built with silty sand, supports a core composed of clay and has a drain filter to collect the small leaks that may have occurred during the construction of the dam or reservoir as shown in figure 1.

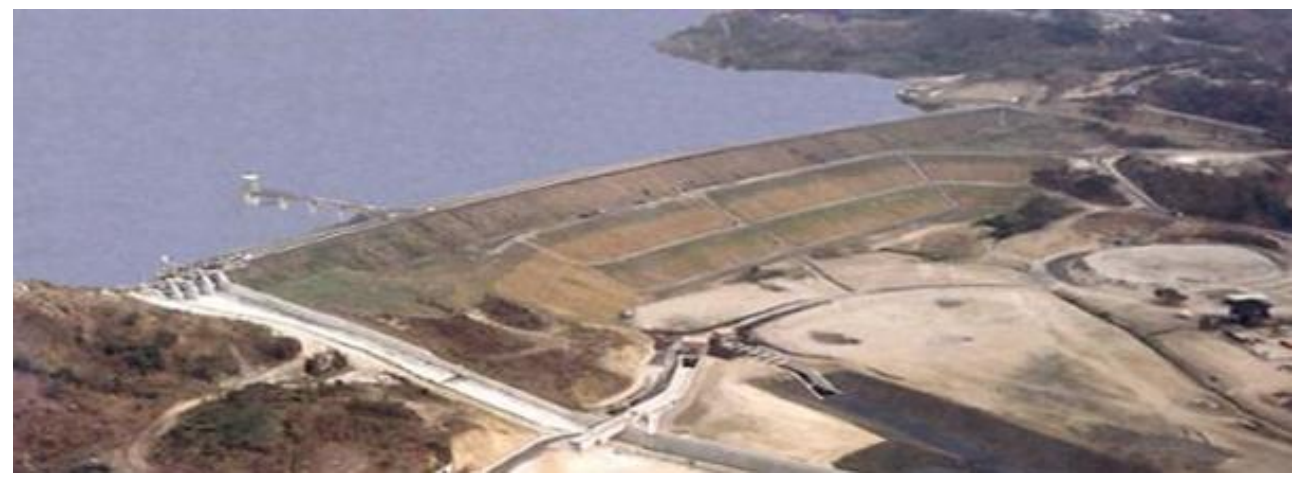

Figure 1. Image of the La Esperanza dam

Parrales, G. S., Giler, B. I. C., \& Alcivar, M. S. G. (2018). Packaging sixto duran ballen and the dam la esperanza. International Journal of Physical Sciences and Engineering, 2(3), 43-50. https://doi.org/10.29332/ijpse.v2n3.199 


\section{Construction of the La Esperanza dam}

Began in 1970 to 1975 with the study of the reservoir dam, under the project of the hydrological-economic feasibility plan in the province of Manabí, in 1976 design the dam proposed by the Agra-Rsalzgitter Integral Association, in 1978 (August), thanks to an international competition, the construction was given to the company Daewoo International, in 1981 the construction was stopped due to the poor foundation conditions, hurrying for later to solve the problem, In 1982 to 1983 Intecsa company of Madrid and Geosisa company of Quito begins its construction making adjustments to the design of the hydraulic model, to the drainage works of bottom and the work takes of irrigation, being in 1992 when the dredging is realized by the Company Dragados y Construcciones SA ending with the execution of the La Esperanza Dam project.

In 1992, the dam had certain drawbacks, so the updated design of the dam is immediately requested. Figure 2 shows an image of the dams of the dam.

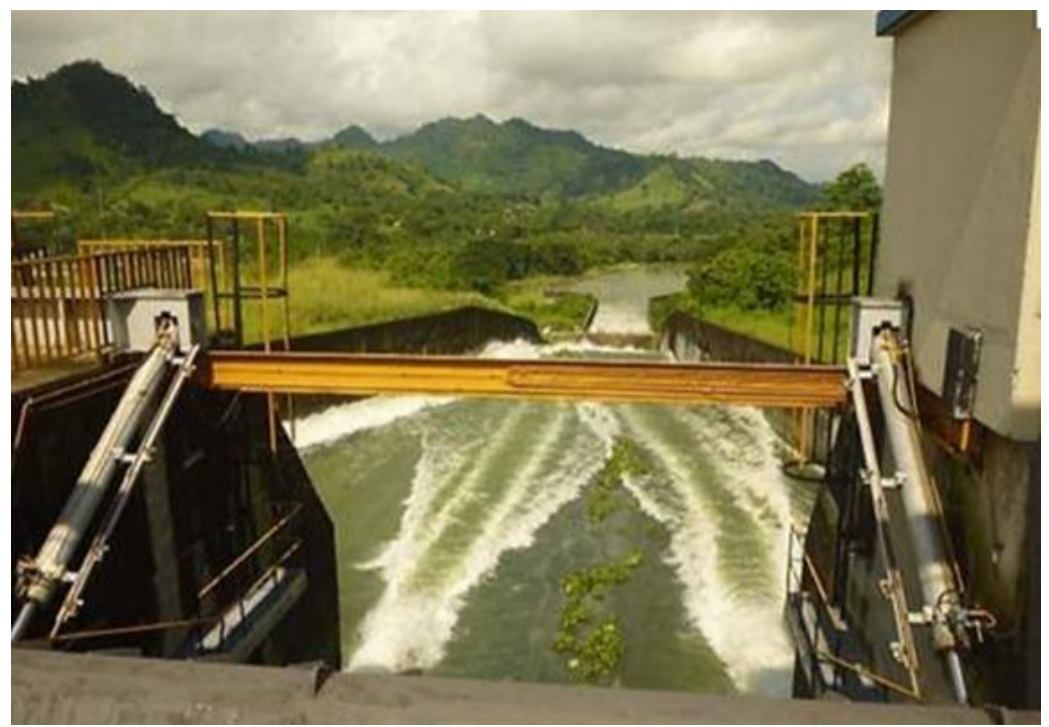

Figure 2. Gate of the La Esperanza Dam

The dam is constituted by:

GatesBody of the dam. Constituted by loose materials, it is of the type of dam that has a central core of clay and gravel or sandstone shoulders, it has a height of $47 \mathrm{~m}$, taken from the bottom of the river to the crown that corresponds to the level 69 meters above sea level (msnm), the crown has a length of $696 \mathrm{~m}$, the slopes upstream and downstream, the base of the dam is estimated at approximately $300 \mathrm{~m}$. In this redesign, the cofferdam is maintained and it is located at a height of 48 meters above sea level, between the slope downstream of the core and the shoulder a gravel drain with graded granulometry was located, which at the base of the dam continues its path in the sense and up to the foot downstream. The slopes were protected, the upstream with a breakwater and the downstream with grass to prevent erosion in the winter time.

Foundations. There is a deep paleo channel that is estimated to be at the level of 20 meters above sea level. It was generated by the channel of the Carrizal River, which was filled with pebbles and sands.

Plastic concrete screen. In order to avoid the filtration due to the flow rates and the possibility of suppressions that affect the stability of the dam, the construction of a plastic concrete screen was designed as an improvement, this element is linked to the core of the dam and crosses the alluvium in terms of depth is 60 meters. The improvements are schematized in the following way: Change of mortar to plastic concrete; Greater thickness at the base of the screen $(1 \mathrm{~m})$; Different construction system of joints between the panels.

It was chosen in the redesign to build the plastic concrete screen because it guarantees to follow the deformation of the land and once consolidated offers great quality; under the practice of the finite element 
method, the deformation modulus is shown which is equal to 150 Mega pascals (Mpa). The thickness of the screen changed to 30 meters deep with a thickness of 1 meter which ensures the sequence of the screen with better reliable margins. The pipes that existed in the joints were changed in order to avoid problems in the future and were replaced following the following procedures: Excavation for the primary panels, cleaning in the excavation, and change of bentonite mud by mud without sand at the end of the excavation, emptying of the plastic concrete, an intermediate secondary panel was excavated and emptied, the panel controls around $0.40 \mathrm{~m}$.

This redesign of the joints ensures the operation of the dam controlling filtration as a barrier. In the construction of the screen $10,035, \mathrm{~m}^{3}$ of plastic concrete and 863 tons of bentonite mud were used. The total length was 240 meters, the deepest panel is 49 meters with an area of $9,925 \mathrm{~m}^{2}$.

Injections. Injections of waterproofing were made in the curtains of the slopes, both right and left, injection to consolidate the foundation, in the landfill, in the gallery and tunnels between the filling lining and the concrete lining and the excavation.

Trilinear waterproofing curtain. The trilinear curtain was injected with the descending method in the sections of 5 linear meters, without getting a secondary treatment with hose cuff, in order to ensure the injection of the upper $20 \mathrm{~m}$ depths. The injection pipe was made with $63 \mathrm{~mm}$ diameter PVC pipe with 2 holes per linear meter. The first 44 drilled holes gave an average intake of $143 \mathrm{~kg} / \mathrm{ml}$ of perforation, then the test wells were carried out with permeability tests.

The bilinear screen of Jet-Grouting in right margin.- Between the origin of the plastic screen and the right margin, of $72 \mathrm{~m}$ in length, the execution of a monolinear curtain of conventional injection was planned; the permeability tests carried out in some test wells evidenced the low efficiency of this treatment, especially in the levels of sandwiched a column between the level +20 and +50 which was decided to execute a Jet-Grouting column composed of two rows of columns staggered with a spacing between column of $0.60 \mathrm{~m}$ and $0.52 \mathrm{~m}$ between rows. The treatment parameters applied were as follows: Injection pressure: $400 \mathrm{~kg} / \mathrm{cm}^{2}$, essential speed: $6.7-8 \mathrm{~mm} /$ s., Rotation speed: $16-35$ revolutions per minute. Nozzle diameters: $2.2 \mathrm{~mm}$, Grout dosage: ratio A / C in weight 1: 1.

The bilinear screen of Jet-Grouting in the left margin.- On the left slope, the treatment was planned by means of a trilinear injection curtain with the origin in the plastic concrete screen, but due to problems of the presence of a breccia zone which are the constituent materials of the slope that was confirmed by reconnaissance surveys executed later. Based on these results with the same characteristics are the JetGrouting treatment with the same characteristics as the one executed on the right margin, reaching excellent permeability value.

Protective dam.- It is conceived as a trapezoidal section filler whose $6 \mathrm{~m}$ wide crown is at a height of 48 masl and its slopes have slopes of 3: 1 upstream and 2: 1 downstream. The deepest level of the foundation is 20.00 meters above sea level, so its height is 28 meters. The upstream shoulder has a $35 \mathrm{~m}$ wide stabilization berm at a height of $35 \mathrm{~m}$ and a slope of $4: 1$. Regulatory effect of the reservoir.- The design flow of the landfill was obtained by analyzing the discharge of the flood hydrograph, with a return period of 1,000 years, normally operating the four dump gates. The results of the studies are shown in table 1.

Table 1

Results obtained in the regulation

\begin{tabular}{ll}
\hline Maximum tributary flow & $3.062 \mathrm{~m}^{3} / \mathrm{s}$ \\
\hline Maximum flow effluents & $885 \mathrm{~m}^{3} / \mathrm{s}$ \\
\hline Maximum level of the reservoir & $67,75 \mathrm{msnm}$ \\
\hline
\end{tabular}

Parrales, G. S., Giler, B. I. C., \& Alcivar, M. S. G. (2018). Packaging sixto duran ballen and the dam la esperanza. International Journal of Physical Sciences and Engineering, 2(3), 43-50. https://doi.org/10.29332/ijpse.v2n3.199 
Therefore, the landfill was designed for the flow of $900 \mathrm{~m} 3 / \mathrm{s}$ and the Bradley profile of the control section was defined for a $5.75 \mathrm{~m}$ slope on the level 62 meters above sea level. In addition, different verifications were carried out for different years of exploitation and the results are shown in table 2 .

Table 2

Verifications carried out

\begin{tabular}{ll}
\hline Flood discharge of 500 years & \\
\hline $\begin{array}{l}\text { Maximum affluent flow. } \\
\text { Maximum effluent flow. } \\
\text { Maximum level of the reservoir. }\end{array}$ & $789 \mathrm{~m}^{3} / \mathrm{s}$ \\
\hline Discharge from the 150-year-old flood. & $67,35 \mathrm{msnm}$ \\
\hline $\begin{array}{l}\text { Maximum affluent flow. } \\
\text { Maximum effluent flow. }\end{array}$ & $2.148 \mathrm{~m}^{3} / \mathrm{s}$ \\
\hline
\end{tabular}

\section{Conclusion}

The information collected about the Sixto Durán Ballén Reservoir and its La Esperanza dam shows that this hydraulic structure is one of the most important in the province of Manabí since it is a reservoir destined to multiple activities. We described the parts by which the dam is composed as the foundation, location, structure and of course that meets the period for which it is designed.

\section{Acknowledgments}

The authors would like to thank the reviewer of the International Journal of Physical Sciences and Engineering for their consideration to the further step round to be accepted the article. The thank also goes to the editor of the journal for their valuable time, support, and advice. 
References

Arismendi, MOR (2018). Mega dams are not clean energy. Ecology in Bolivia 53 (1): 1-6. April 2018. ISSN 1605-2528.

Inostroza, G., \& Cànoves, G. (2014). Sustainable tourism and hydroelectric projects: contradictions in patagonia, chile. Cuadernos de Turismo, (34), 397.

Introduction ", BioScience, no. 9, vol. 50, pp. 746-751.

Lay, D. (2018). Dam construction analysis in Indonesia. International Journal of Social Sciences and Humanities, 2(2), 252-264.

López-Pujol, J., \& Poncenti, M. (2008). The project of the three Gorges of China: S history and its consequences. Studies of Asia and Africa, XLIII (2), 255-324.,

Martínez Yrízar, A., Búrquez, A., \& Calmus, T. (2012). Disyuntivas: impactos ambientales asociados a la construcción de presas. Región y sociedad, 24(SPE3), 289-307.

Ribera Arismendi, M. O. (2018). Las mega represas no son energía limpia. Ecología en Bolivia, 53(1), 1-6.

Rosenberg, D. M., McCully, P., \& Pringle, C. M. (2016). Environmental Effects of Hydrological Alterations.

Parrales, G. S., Giler, B. I. C., \& Alcivar, M. S. G. (2018). Packaging sixto duran ballen and the dam la esperanza. International Journal of Physical Sciences and Engineering, 2(3), 43-50. https://doi.org/10.29332/ijpse.v2n3.199 


\section{Biography of Authors}

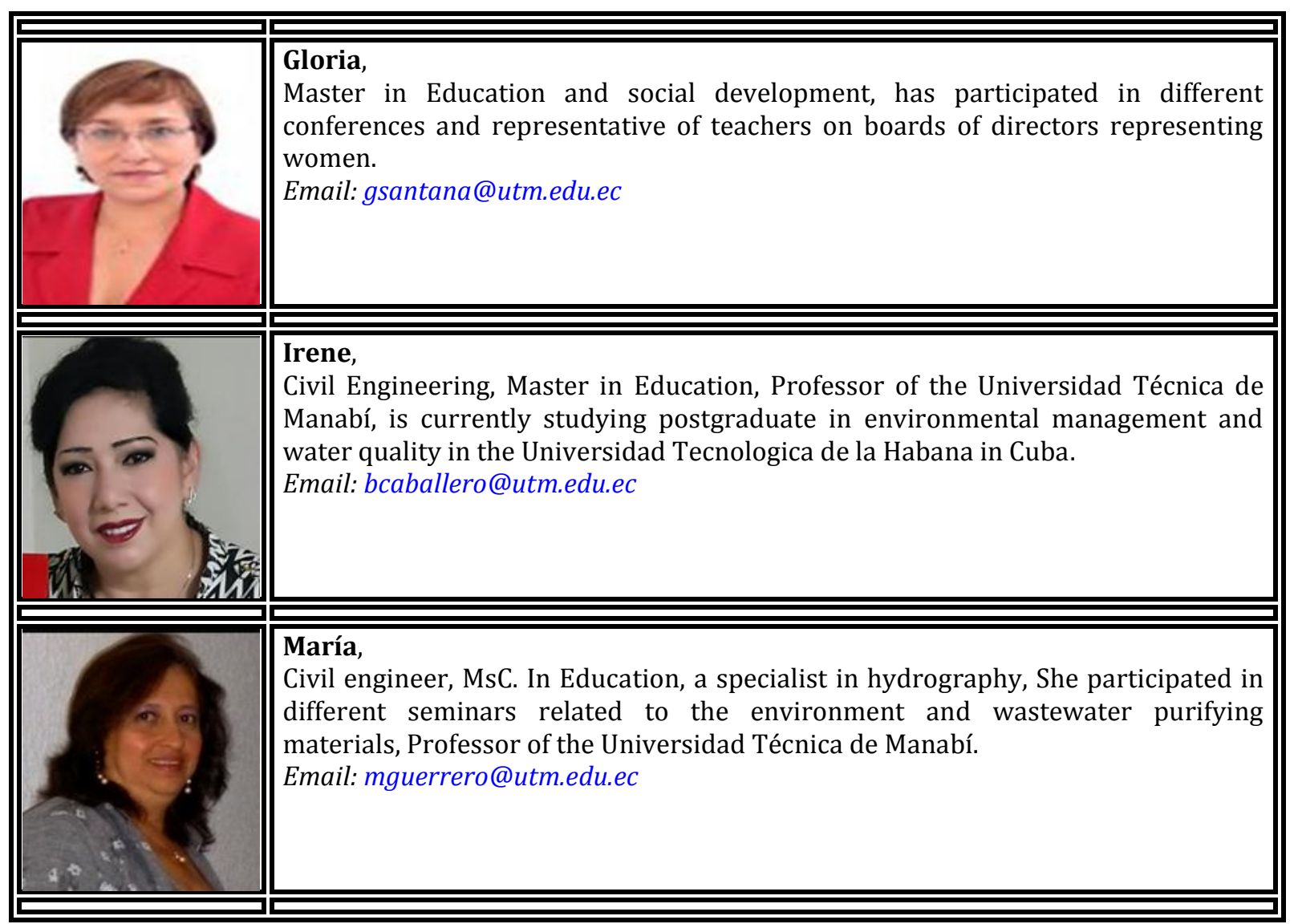

